\title{
Participatory Theatre as a Practice as Research Tool for Engaging with Young Men to Interrogate Masculinity and HIV in Malawi
}

\section{Cover Page Footnote}

Zindaba Chisiza is lecturer in Drama in the Departement of Fine and Performing Arts at the Universtiy of Malawi. He recently submitted his doctoral thesis entitled Deadly masculinities: Towards a theatrical toolbox for exploring identity and HIV with young Malawian men" at the University of Leeds. He is a Theatre for Development practitioner and theatre producer/director. His current research interests include participatory theatre, health and development communication, and performance studies. 
This article is about a series of participatory theatre-based workshops that I conducted with a group of male students from the University of Malawi between February and June 2015. In Malawi, young men are at high risk of acquiring HIV because of pressure to perform sexually risky behaviors (not using condoms and having multiple sexual partners) in order to assert themselves as men. The failure to engage men in challenging and changing dangerous constructions of masculinity will continue to leave women vulnerable to infection and perpetuate the spread of HIV. Using workshop and performance vignettes, I illustrate how theatre-based methodologies facilitated the investigation of masculinity and HIV, and enabled young men to consider solutions for change. I argue that this work impacted participants, and shows real potential for wider use in communities similarly affected by both HIV and social assumption about male sexual behavior. In order for real change to occur, however, this work needs to be further developed and younger boys and girls need to be empowered to openly discuss sexuality, gender identity, and HIV.

\section{A Brief Background}

In Malawi, the use of Theatre for Development (TfD) - others have referred to it as popular theatre and community theatre-for HIV prevention dates back from the early 1990's. When the first cases of HIV were reported in the late 1980's, President Hastings Kamuzu Banda's government (1964-1994) did not allocate adequate funds to combat the disease. ${ }^{1}$ In 1994, Banda's rule ended and the country became a multiparty state; however, things did not change. Consequently, the fight against HIV became the responsibility of NGO's, which then turned to theatre as a tool for making people aware of the dangers of the disease. ${ }^{2}$ Since then, TfD has been used in Malawi as a messagegiving tool in the fight against the spread of HIV; the program promotes Abstinence, Being Faithful, and Condom use - the ABC approach. ${ }^{3}$ Although the current uses of TfD have definitely resulted in raised levels of awareness, the disease, tragically, continues to spread. ${ }^{4}$

It is estimated that in Malawi $10.6 \%$ of the population are living with HIV. ${ }^{5}$ Today, $50 \%$ of new infections occur among people aged 15-24; for males the rate is $2.5 \%, 3.6 \%$ for females. ${ }^{6}$ Among heterosexual couples HIV transmission is driven by male risky behavior, gender inequality, and cultural practices that enhance men's dominant social position over women, especially in sexual matters. ${ }^{7}$ In their recent 
studies on young Malawian men, Chimaraoke Izugbara, Jerry $\mathrm{Okal}^{8}$ and Amy Kaler ${ }^{9}$ found that men are at risk of HIV infection because of pressure to enact high-risk sexual behaviors, such as not using condoms, having multiple sexual partners, and controlling the terms under which sex occurs in order to affirm what they consider "real" masculinity. ${ }^{10}$ Anti-HIV campaigns in Malawi that target men do not explicitly tackle how certain conceptions of masculinity put men (and their partners) at risk of infection. Izugbara and Okal argue that HIV interventions for men in Malawi seek to promote "sexual abstention, partner reduction, faithfulness and condom use." ${ }^{11}$ They further argue that such campaigns are ineffective because for many male youths, taking on risky sexual practices is part of a strategy for becoming what they and society see as a "real" man. This then prompts the question, given such deeply accepted narratives about masculinity: can simple messaging about $\mathrm{ABC}$-related choices reach deeply enough into embedded cultural norms that young men are enabled to interrogate how certain Malawian masculinities actually encourage the spread of HIV?

\section{Why Theatre?}

Can theatre help young people to openly talk about HIV and gender? There are a number of arts-based projects, developed by DramAidE in South Africa and TUSEME in Tanzania, that provide evidence of participatory and dialogic approaches empowering youths to analyse their problems and to find solutions. In 1991, Drama in AIDS Education (DramAidE) was formed in the department of Drama at the University of KwaZulu, with the aim of using educational drama and theatre-based techniques in secondary schools "to effect change in knowledge and attitudes about the transmission of HIV/AIDS and to contribute towards healthy behavior patterns." 12 Initially, DramAidE's approach involved a team of actors gathering information about knowledge, attitudes and behavior, and then presenting a play-based on that information - to a target school. This was then followed by a series of workshops whereby the students analyzed the issues in the play. The final stage involved the creation of art forms (play, dance, song, poetry or poster) by the students themselves; these performances were then presented to their peers.

According to Lynn Dalrymple, between the late 1990's and early 2000's, HIV prevalence in South Africa continued to rise, and it became clear that information-based theatre alone could not change behavior. ${ }^{13}$ In order to empower young people to examine social forces that encourage HIV, DramAidE adopted life skills clubs in 
schools. The idea was that though these clubs young people could educate each other through the arts. ${ }^{14}$ Dalrymple says that in the youth clubs, theatre-based techniques were used to create a "process of community problem identification, group decision making, action planning, collective action and implementation." 15 Currently, DramAidE is still ongoing and working with young people on sexuality, gender, and HIV.

TUSEME (Let Us Speak Out) model was initiated in 1996 by the Department of Fine and Performing Arts in the University of Dar es Salaam (Tanzania) as a secondary school girls' empowerment programme, under the patronage of the Forum for African Women Educationists (FAWE), Tanzania chapter. ${ }^{16}$ The aim of the program was to use theatre-based techniques to enable girls to interrogate the barriers to academic and social development and to find solutions for overcoming them. ${ }^{17}$ In the TUSEME model students actively participate in investigating the issues that relate to girls' and boys' academic and social development. The problems are examined and solutions for change tried out in a workshop setting, before a play based on these issues is created. The play is presented to their peers in order to facilitate critical discussion. During this discussion, the audience is encouraged to analyze the problems and to offer strategies for action. The next step involves students coming up with an implementation strategy for the action plans proposed during the discussion. The final stage of the process includes students receiving training in life skills, in order to help them overcome gender-based barriers to education and self-development - this is then followed by the establishment of TUSEME school clubs. The impact the models has had on girls in Tanzania has included improved academic performance, reduced number of school dropouts and a drop in unwanted teenage pregnancies. ${ }^{18}$ By 2004 the TUSEME program had been implemented in 17,000 schools and across 13 Sub-Saharan African countries including Malawi. ${ }^{19}$

A key feature of the approaches by DramAidE and TUSEME is the centrality of young people as agents of change, capable of analyzing their problems and finding ways of overcoming them. What also makes the work by DramAidE and TUSEME effective is the use of participatory and dialogic theatre forms to facilitate critical debates on issues with young people in a meaningful way that can lead to change, as opposed to TfD for HIV practices in Malawi which seeks simply to transmit messages and, arguably, impose solutions. 


\section{Towards an Arts-Based Anti-HIV Approach for Young Men in Malawi}

Between February 2015 and June 2015, I worked with a group of male students from the University of Malawi's Chancellor College campus on an arts-based project as part of my practice-led doctoral research. The participants, aged 19-24, came from a range of disciplines (Law, Drama, Media for Development [MfD] and Philosophy). Participant recruitment involved a briefing session where participants were told about the aims of the project and given the opportunity to ask questions. Participants were free to drop out of the project at any point.

The project set out to examine the effectiveness of a range of theatre-based methodologies (Image theatre, Playback theatre, Forum theatre and local art forms) as dialogic tools for enabling young men to examine dangerous masculinities and ways of dealing with HIV risk. My work was primarily focussed on discovering which were the most impactful, theatre-based methods for helping young men to construct "positive" masculinities, and create a safer sexual environment for both the men and their (prospective) partners. By the term "positive", I am referring to masculine gender identities that are devoid of risky and controlling behaviors, and gender-based violence. My work was based on the hope that participatory theatre methods, alongside dialogic discussion, could empower the young men to "externalise their systems of beliefs and, on the other hand, to step back from them so that they may gain perspective."20

Apart from this, I also wanted to find out how theatre as a research tool could help me in understanding how young men in Malawi are defining themselves as male, and the personal harm that emerges in relation to those definitions. From my wider reading I was aware that some theatre forms worked better as generative tools, whilst others worked well as diagnostic tools. By this I mean that generative techniques produced, illustrated and embodied themes of masculinities, while diagnostic forms enabled the participants to critically examine and problematize these ideas of manliness. These qualities informed my choice of techniques.

\section{Workshops At Chancellor College}

Work at Chancellor College began on 22 February 2015. We began with drawing autobiographical posters. The participants were asked to draw something that described their life: the type of man they believed themselves to be, and who they aspired to be in future. The drawing depicted "ideal" masculinity as: having girlfriends, 
possessing wealth (such as a house and car), and being married, with children. The drawing continued on day two. The participants were now asked to create an image that showed how they had learned to be a man: what being a real man meant and what are the associated privileges.

The posters revealed that the majority of the young men had learnt about being a man from their fathers, or a father figure, and through gender role assignment within the family. For some of the participants, "ideal" manliness was being both physically and emotionally strong; for instance, men were depicted as extremely muscular, or leading women and children.

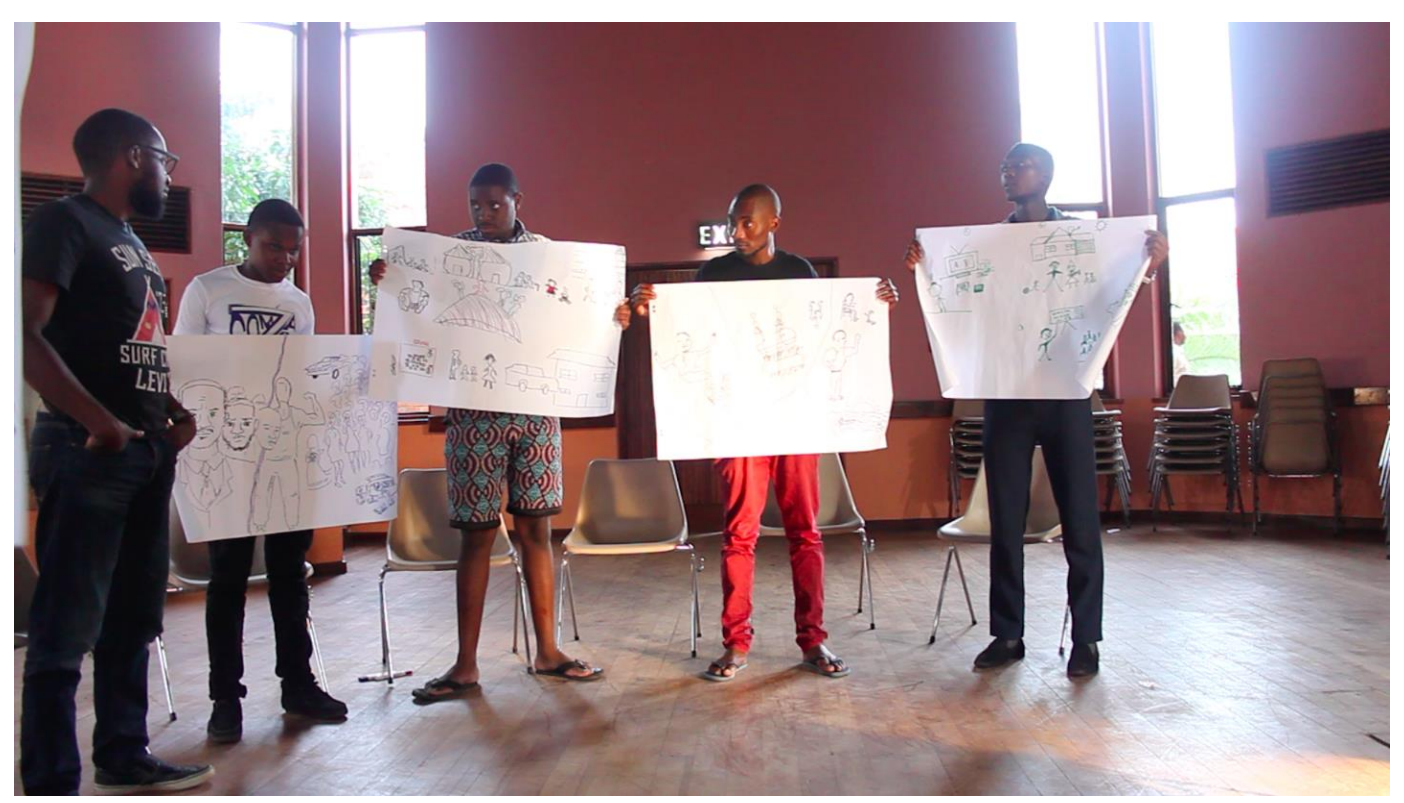

Figure 1 - Participants at Chancellor present their autobiographical posters.

During the poster presentation, the issue of sexuality also emerged. One of the participants stated that a man had to procreate and know how to sexually satisfy his partner. A majority of the participants agreed that this was essential, because failure to do so resulted in a woman leaving or cheating on him. The group claimed that a man had to learn new sexual techniques and be skillful in bed by having multiple sexual partners. I was curious about what safe sex strategies the young men used when engaging in these practices. Those who were sexually active explained that condoms were for penetrative sex and not for oral sex, even if the girl was not a regular sexual partner. During the debate, it emerged that the group was not aware that some sexually transmitted infections (STIs) can be transmitted orally.

An analysis of the posters produced through the drawing of autobiographical narratives revealed that the participants' ideas about masculinity were strongly 
associated with sexual performance, financial independence and fatherhood. What struck me was that the group considered wealth, marriage, and having children as desirable attributes of a post-university successful masculinity; yet they believed that having sex with multiple sexual partners enhanced one's masculinity. Such a contradiction is well explained by Walker et al. who argue that when economic prospects are low for young men, the trend is to find other ways of proving masculinity - by having sex with multiple sexual partners and taking on other risky behaviors. ${ }^{21}$ The participants' narratives about masculinity based around sexual performance confirm what Baker and Ricardo also found in their study on youth masculinities in Sub-Saharan African. ${ }^{22}$ They offer the following insight: "the status that a sexually active young man might attain among his peers can sometimes be equally, if not more important, than the intimacy that comes from the sexual relationship itself." 23

On day three, after I felt that I could not take drawing any further in analyzing the issues, I moved on to playback theatre, as developed by Jonathan Fox and Jo Salas. ${ }^{24}$ In Playback theatre a member of the audience tells their story and this is enacted (played back) by the actors. In this particular workshop, participants were asked to think of an incident that had happened to them, one that marked transition from childhood into manhood. Each individual was required to share his story with someone else in the group. Each young man had to find new a partner, until the entire group had shared their personal story. They were then divided into groups of four, and each group had to chose one story to work with from within the group. Once they had decided on a story, the "owner" of the story selected who would act it out. Three small sketches were made, and through the performances of these stories, the following themes emerged: male sexual experience as a marker of masculinity, and men as protectors of women. On day four we continued with this method. Two performances were made that each revealed that being defeated in a physical confrontation and becoming a teenage father caused a crisis in one's masculinity.

The story about teenage fatherhood enabled us to unpack the young men's ideas about safe sex practice. The story was about a participant's girlfriend, who became pregnant after they had agreed to stop using condoms. After performing the story, it was time to choose an alternative ending. The thinking in Playback theatre is that through changing the outcome of the event, the participants are able to explore strategies for change. Notably, the crisis in masculinity was caused by having caused 
an unwanted pregnancy and entering fatherhood while still financially dependent on parents. The story's "owner" said: "if I could change something, I would not have forgotten to use protection [condoms]." When asked why he had stopped using condoms in the first instance, he replied: "I felt in love, we felt that we could trust each other and we were committed to each other." I then asked why he thought not using condoms was an expression of love and he offered the following explanation:

When you are feeling so committed to a person, you use condoms, but at some point, you stop because you have sex a lot [...] then you feel like you can trust each other and you do away with the condom. The problem is that I was scared of getting STIs or HIV/AIDS, but after going for testing I knew I could trust her.

At this point I asked the other participants what would lead them to stop using condoms. One participant said that trust and commitment often led to irregular condom use, or using no condoms at all. A final year Philosophy student offered a different perspective when he argued: "It is beyond commitment, I think it is the sweetness of plain sex," which drew laughter and applause from the group. Asked if the issue of HIV and STI risk ever came up, they claimed that condoms are not needed if an HIV result is negative. The young men's narratives about commitment and trust leading to noncondom use is confirmed by other research. For example, in their study on condom use among South African youth, Catherine MacPhail and Catherine Campbell found that regular relationships mitigated the use of condoms, rather than "a negative HIV status or discussion about sexual histories as the main reason." 25

It was at this point that I realized that Playback theatre could not take things further because of its reliance on participants' past experiences as a form of selfcritique. It was time to introduce Image theatre, as developed by Augusto Boal, ${ }^{26}$ and I did so on day five, in order to help the participants analyze their identity construction and the gender inequalities inherent in their relationships. In Image theatre, the participant(s) create a tableau of an issue and other participants intercept their image to draw out meaning. ${ }^{27}$ Participants were asked to make images of something that oppressed their masculinity. I divided the participants into three groups. One of the groups created an image of a man and woman, he with his pockets turned out, signaling his wife to come towards him, while the woman shrugged her shoulders. The interpretation by the group watching was that the man was being denied sex because he could not provide for his wife financially. I asked the group if they had experienced this problem and most assented. 
The next step required participants to change the image, and to do so by removing the oppression. When asked what strategies the man could use to overcome his problem, participants suggested that he could find another woman. When the image was changed, the man was seen carrying bags of groceries. The participants said that without providing for a home, the man will not have access to the woman. In my observation, the root problem was that sex was being seen as a financial transaction. In response to this, I set up a final stage that involved creating an alternative image: one that demonstrated ways in which a man without money might claim his "manliness." These new images displayed men as protectors and caretakers of their girlfriends. The construction of an alternative "positive" masculine gender attribute was a significant step forward for the participants, given the retrogressive ideas of masculinity that kept emerging.

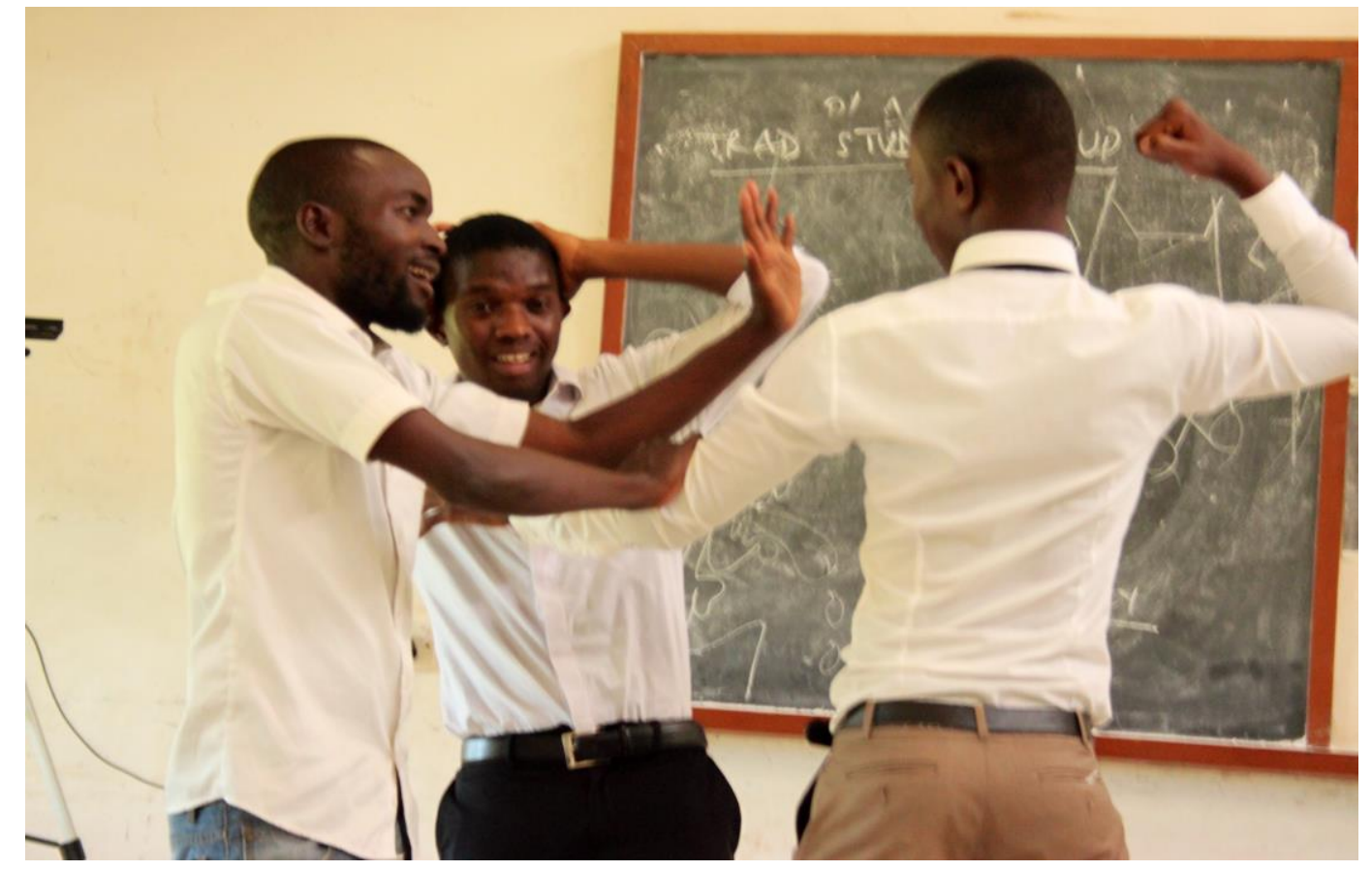

Figure 2 - Participants at Chancellor enact a caring and protective masculinity using Image theatre.

Some of the most important Image theatre work happened on days six and seven. The participants had to make an image that showed ways in which men could enact masculinity in relationships without money. The first tableaux showed a man standing behind a woman, his hands on her shoulders. According to the group, the interpretation was that a man is a pillar - financially, physically, and emotionally-and is a leader of the woman. The image work here revealed the young men's patriarchal 
views regarding gender roles, which in turn informed their ideas of manliness. For the group a "real man" was defined by his access to wealth and material trappings-owning a house, a car, being successful and getting married were all seen as important features of masculinity. In the words of a final year drama student; “Once you are successful, women actually chase after you."

I then asked the group to examine the power dynamics of the couple in order to see if there truly was equality. One of the images made illustrated a man and woman looking at each other, with their arms across each others' shoulders. One participant stated that the image suggested that the man and woman were willing to compromise on things, despite having different views. The image was then changed again and this

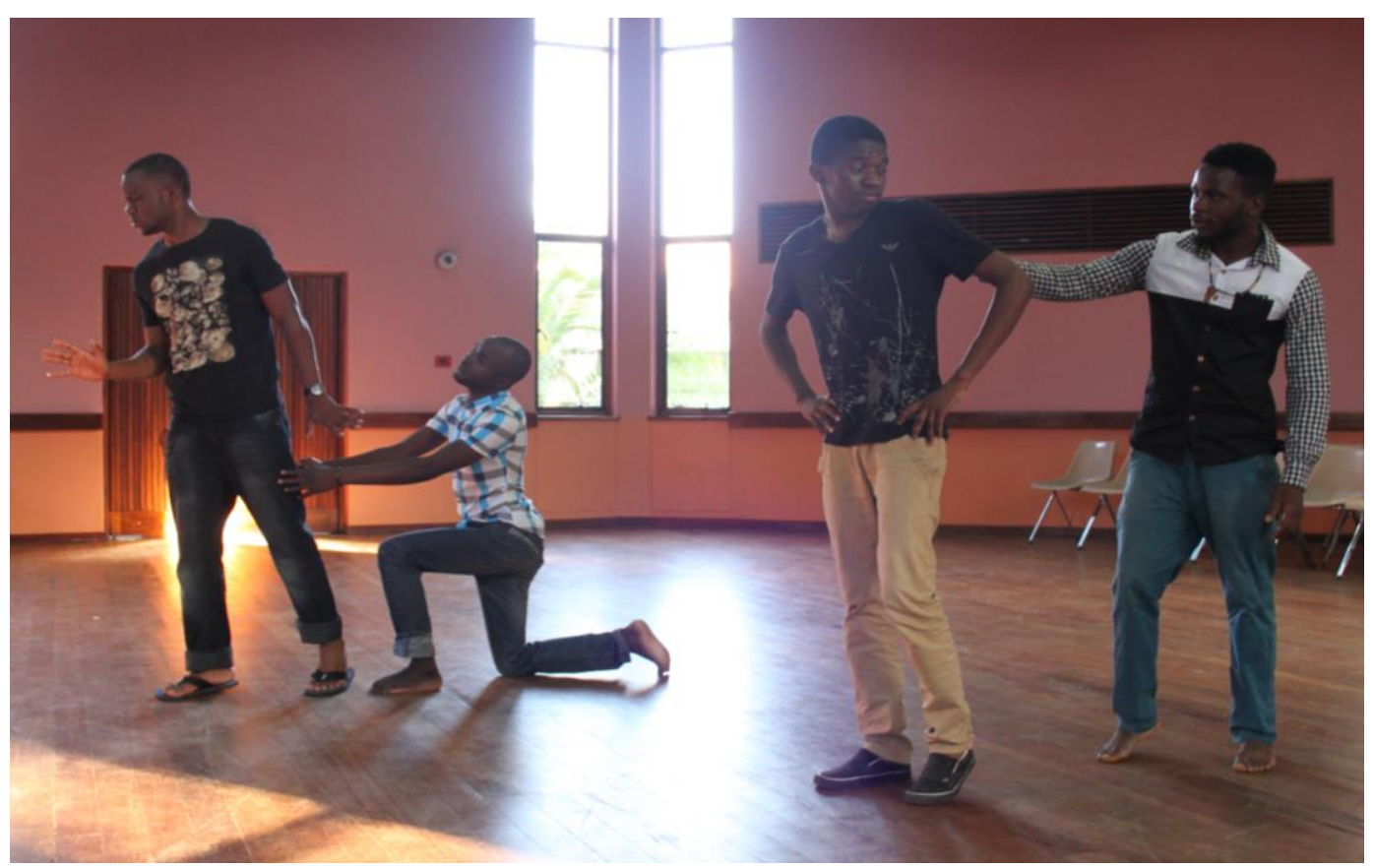

Figure 3 - Participants exploring sexual consent using image theatre

time, the man's hand was placed on the left rib cage of the woman. The interpretations included one suggesting that "the man wanted to show the woman that he will always be there for the woman."

The participants were then asked to make images showing gender power dynamics within sexual relationships. After the images had been created, I asked the group to examine the power dynamics in their image. The exchange went as follows:

Facilitator: Can we take a look at this image. What does it say?

Participant 1: She is saying cool down and he is insisting on having sex with her.

Facilitator: Anyone else with a different idea? 
Participant 2: I do not think there is a consensus here. The man wants sex and the woman is not ready.

Facilitator: Does a conversation about condom use start here?

Participant 3: No, I do not think so. I think it would happen at a later stage when you are to engage in the sexual act. That is when you think of pulling out a condom. At this stage, you do not talk about condoms. This time is for kissing and stuff. You do not have time to be talking about condoms, you get bored.

Facilitator: If there is no agreement, can the woman tell the man to put on a condom?

Participant 4: Judging from the image, she is pushing him back a bit.

Facilitator: Why is she pushing him back?

Participant 4: This could be a conversation to use a condom.

Participant 5: In this case, the condom cannot be used. The guy wants sex and the girl is refusing. Assuming that the girl is playing hard to get then the guy will just insert his penis fearing that she might start refusing again.

Participant 1: When you get a girlfriend, it is very difficult for a Malawian lady to agree to have sex without a struggle. Usually most boys force themselves on the girls.

Participant 6: Usually their refusal is not rejection, rather it is tactical, they do not want you to see them as cheap. So they refuse while they want.

Facilitator: How do you know that it is tactical?

Through Image theatre, the use of force and coercion in young people's sexual relationships emerged as a dangerous form of masculinity. The participants claimed that the use of force in sexual relationships was normal, as women did not give into sex easily. The participants told me that sex attained under these conditions is often risky because most men are afraid the girl will change her mind, and this will mean the couple will end up having unprotected sex. This has huge implications on safe sex for HIV 
risk. I would also argue that this experience for girls causes serious psychological (and physical) harm. Writing on power dynamics in young people's relationships, MacPhail and Campbell say that "inequalities in power between male and female partners in heterosexual relationships holds sway over the ability of young women to either refuse sex or negotiate the use of condoms." ${ }^{28}$ While participants expressed fears of contracting HIV, their sexual behaviors were contradictory to this understanding

I felt that the group needed to be both challenged and enabled to think about how they could attain clear and verbal sexual consent from their partners-without coercion. On day seven we continued with Image theatre. The participants were asked to create three images: the first had to depict no consent; the second was to show that consent had been granted; and the final image had to show what young men could do to arrive at image two. The images revealed that consent could be attained through a two-way form of communication; preferably before foreplay or sex, and in the words of words of one participant: "Both men and women need to be empowered to openly discuss sexual matters."

\section{A Virtuous Masculine Gender Identity?}

The participants returned from their three-week break at the end of May, and we resumed our workshops. On day one, the participants agreed that they wanted to make a video documentary composed of student interviews, testimonies from the group, and performative interludes: music, poetry and spoken word or rap music. The aim was to answer what it means, for male university students, to be a "virtuous man." I decided that this was the direction where the workshops needed to go, because the participants had begun exploring ways of forcibly obtaining consent from their girlfriends. Moreover, many of the ideas and images of masculinity the young men were generating were sexually risky and oppressive. I felt strongly that the participants needed to be enabled to think about masculinity in more positive ways.

The idea of the virtuous man was inspired by a Christian student bulletin that had been posted on a noticeboard outside the college library; it had featured a number of female students talking about the qualities of a virtuous woman-qualities they claimed to possess. Briefly, the biblical characteristics of a virtuous woman are outlined in the Old Testament Scripture of Proverbs 31: 10-31. The woman in this passage is described as wise, faithful, industrious, kind, hardworking, loving, caring of the poor and full of dignity. This inspired me to ask the group what the characteristics of a 
virtuous man would be. The group was intrigued by the concept and set out to find possible answers. In the discussion, a number of interview questions were developed. Does a virtuous man seek sexual consent from his girlfriend? Is he respectful of girl's wishes? Does he practice regular condom use? Does he sleep around with multiple, concurrent partners? Would he know his and his partner's HIV status?

On the second day of this round of workshops, the participants-equipped with video cameras - set out to interview fellow students. An analysis of "virtuous man" interviews revealed that a virtuous man was considered to be one who is aware of his HIV status and his partner's, practices safe sex, is respectful of women, and as one who sought sexual consent without coercion, and who had only one sex partner at a time. Initially, I suggested that the group create Invisible theatre sketches on the issues that had emerged, performances they could include in their documentaries. Invisible theatre requires actors present a "scene in an environment other than theatre, before people who are not spectators." ${ }^{29}$ The central idea is that the onlookers have no idea, at any stage, that they are taking part in a theater event that actors have created in order to invite critical thought and response about an important social issue. This structure invites everyday people to engage conversation about a scene that, to the onlookers, is occurring as part of their normal day in a public space. Several of the participants told me that they had never acted before and they found this new method intimidating. I then proposed devising a Forum theatre ${ }^{30}$ play instead, as this would give us enough time to rehearse. Moreover, one of the drama students could facilitate the Forum session. We worked on the play for three sessions. A female student in her final year helped us by performing the female role. We titled the devised work Status.

\section{Status: A Forum Theatre Performance about HIV Disclosure and Masculinity}

The play tells the story of a male university student, Mabvuto, who is a virgin. When we are introduced to Mabvuto he is in a relationship with Linda, a fellow student. Problems begin to emerge when Linda insists that they start having unprotected sex as a proclamation of true love. Mabvuto objects but later on he agrees - on the condition that they first get tested for HIV. At the clinic Mabvuto discovers that he is HIVpositive and Linda is not. Linda accuses him of trying to infect her and leaves. Mabvuto calls his parents to confront them and finds outs that he acquired the virus at birth from his mother. Soon Mabvuto's status is known and all of his friends abandon him. Afterwards, he becomes a devoted Christian. In his final year of school, he meets a 
first-year girl named Alice who is interested in him. A few weeks later the two start dating. Alice asks Mabvuto if they can start having sex, since everyone is doing it. He agrees, but insists that they use condoms. During an HIV awareness week, Alice and Mabvuto meet a group of student peer educators distributing free condoms. Mabvuto tells Alice that they should get more condoms. She objects and argues that they should stop using them as the latex gives her a rash. Mabvuto agrees without disclosing his HIV status and the play ends.

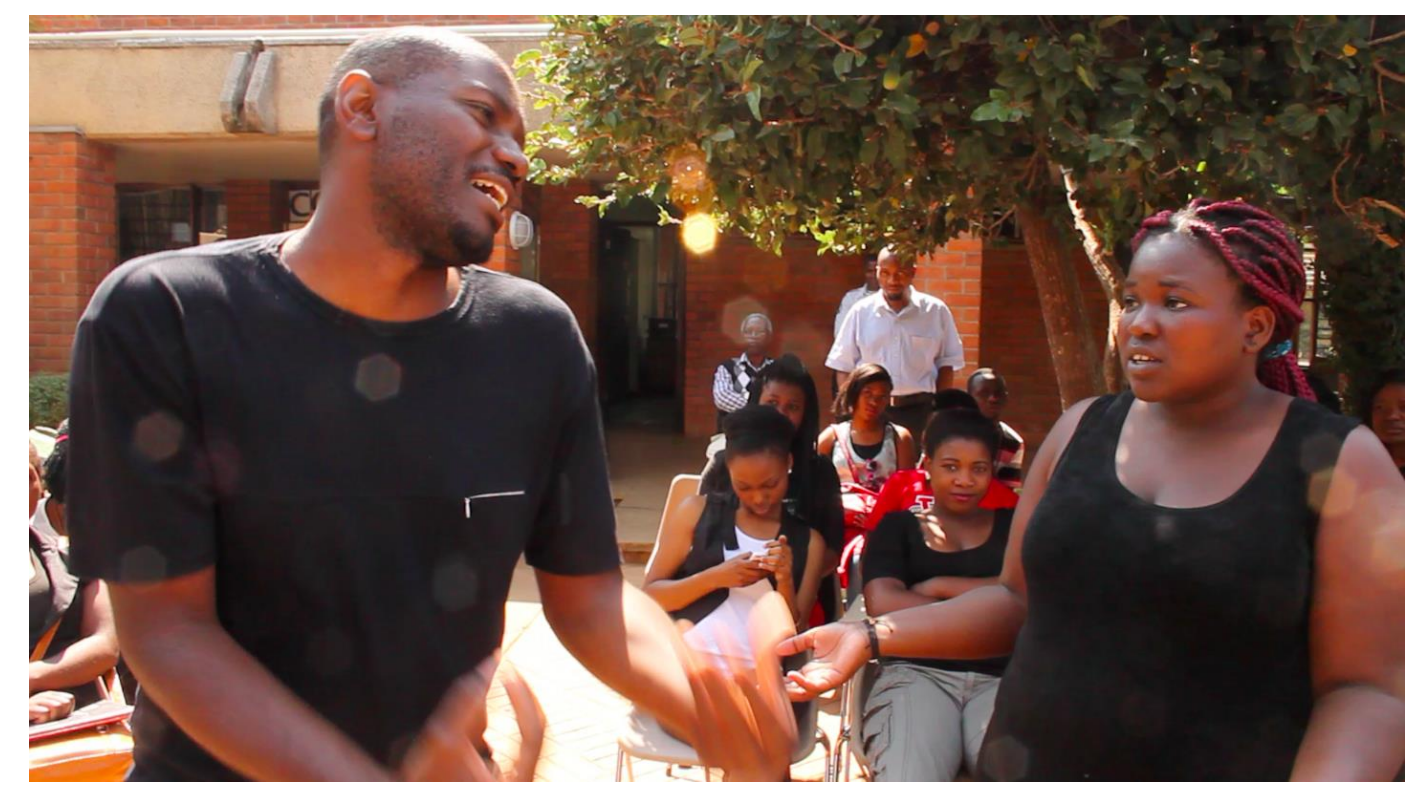

Figure 4 - Status, actors performing a scene at Chancellor

Status was performed at 10am on 31 July 2015, in the open-air theatre at the Department of Fine and Performing Arts. By 9:30 am an audience of students and a handful of academic staff members began to gather. In total, there were about forty-five people. The performance was largely in Chichewa, with some parts in English. It was performed as theatre-in-the-round. The performance incorporated some of the images that were made during the image theatre exercise and musical interludes were used to link scenes. The performance lasted for about 40 minutes.

\section{Forum Theatre}

At the end of the play, the Joker (Forum theatre's facilitator), played by a final year drama student, invited the audience to think about some of the problems they had observed in the play - the audience were also encouraged to offer alternative courses of action that our main characters could have taken. The first person to raise a hand was a male student. His contribution was that when Alice persuaded Mabvuto to have 
unprotected sex, the boy should have refused. At that point the Joker invited him to take the role of Mabvuto and the whole scene was reenacted. The new Mabvuto argued that he could not have unprotected sex as he was HIV-positive. When Alice heard this she became angry and accused him of trying to infect her with the virus, to which Mabvuto argued that if that was the case then he would have agreed to her proposal. The Joker stopped the scene and immediately the actors received a thunderous applause.

The Joker took the stage once more and continued to probe, asking the audience if they had noticed any other problems. For a few minutes, it seemed as though no one was willing to contribute. However, before long a final year female drama student raised her hand. She explained that she wanted to change the scene in which Linda and Mabvuto were arguing about having unprotected sex. The new Linda simply agreed to Mabvuto's proposition that they still use condoms, rather than having risky sex to prove their love for each other. A male student audience member offered a different view. He argued that Mabvuto should have rejected Linda's proposal for sex, rather than giving in. The Joker invited him to take the role of Mabvuto. The scene was re-enacted. This time around, Mabvuto insisted that he and Linda were not going to have sex at all because that was what they agreed in the first place, and that Linda should know that not sleeping with her does not mean that he loves her any less. Another female student said that she wanted to change the scene at the clinic; she felt that the way Linda reacted to the results was unfair to Mabvuto, because his going for an HIV test was a sign of honesty. In the new scene, Linda told Mabvuto that being HIV-positive is not the end of the world and that was possible that he might have contracted the virus at birth-and that she still loved him. Unfortunately, the scene was interrupted by the actor who played the role of the medical doctor, when he decided to chase the actors out of the space. After realising that this was unplanned, the Joker then asked the female student to explain the thinking behind her actions. She went on to say that, despite Mabvuto's status, Linda should have stayed with Mabvuto because leaving him was a form of discrimination. She received applause for her contribution.

Another female student proposed to change how the medical doctor counselled Mabvuto and Linda. She argued that Mabvuto and Linda could have asked for more information that could have empowered them to live positively. The Joker then invited her to enact the scene. This time around two female students played the two roles. When the scene ended, a male staff member offered another viewpoint on the scene. He explained that it would have been helpful if the doctor had informed the couple that it 
is possible to have a healthy and long-term relationship when one partner is positive and the other is negative. A female faculty member suggested that Mabvuto should have told Alice his HIV status before dating her, rather than keeping it a secret. The Joker then asked the audience if students would be willing to disclose their HIV status? At that moment, a female drama student raised an interesting question. She asked: "should HIV-positive students only date those who are positive, or can an HIV negative person date someone who is positive?" The debate then took an interesting turn. In response to the question that was raised, a final year male drama student asserted: "there is a lot of hypocrisy among Christian students on campus who pretend that they are not engaging in sex, when in actual fact they are. This is happening because being seen with a condom makes you the biggest sinner. As a result, many Christians are having unprotected sex, which is helping to spread the disease."

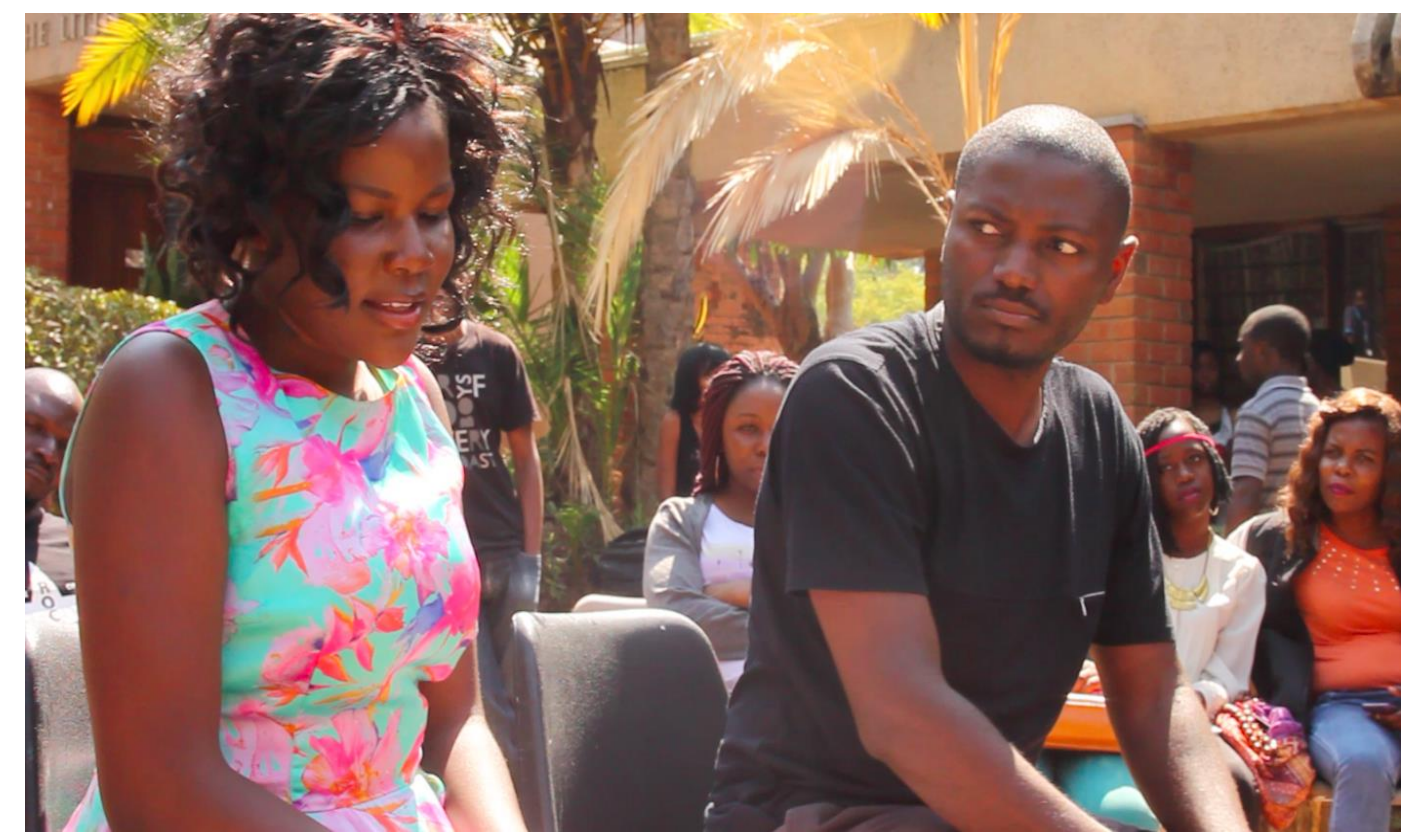

Figure 5 - A young woman audience member offers a solution during a forum scene

Many TfD plays relegate audiences to the position of passive observers, whose participation is limited to chorused responses initiated by actors posing leading questions to them. Our play, however, offered the audience the opportunity to engage with each other in a dialogic discussion. Through Forum theatre at Chancellor College, several young men and women were empowered to talk openly about identity, sexual practices, and HIV. In Malawi, women occupy subordinate positions when it comes to negotiating sex or safe sex practices. By reversing the role that men ordinarily take in the social relationship we had hoped to show an alternative form of masculinity. The 
choice to have Mabvuto's character not disclose his HIV status was used to create a pathway for our audience to engage with the story, and to offer alternative action. It also allowed the participants to hear what other students thought about some of the issues they had been debating.

\section{Impact of Methodology on Participants}

In June 2016, I interviewed six of the participants from Chancellor College to find out if the workshops had been helpful to them. According to two of the respondents, the workshops had been useful insofar as they encouraging the young men to seek proper, non-coerced sexual consent from their partners. One participant said: "I thought it was normal not to ask for consent, but afterwards the workshops I realized that it is necessary." The second participant confirmed this change when he explained: "I believe in consensual sex. Before, I thought if a girl says no, then she actually means yes." One of the drama students, who had been single during the research, added: "there was the issue of a virtuous man. What does he do? I have a girlfriend now and she lives in Blantyre and there were so many chances where I could have entered into relationships with other girls, but I decided that I want to stick with one girl.” Another participant offered a very interesting explanation of how the workshops had brought change. He explained:

Initially, I defined myself based on what my friends said. I felt I have to sleep with a lot of girls in order to be a man. I would go to my friends and say ife ndi ma man, timadya plain (I am a real man because I have unprotected sex). The eight months that have passed have been a time of reflection. I am single but I keep getting sexual offers from girls, which I refuse. If I get a girl, I want to do it out of love and not just for the sake of sex ... I do not want to have meaningless sex.

Although the respondents said that the workshops had helped them, they also admitted that consistently practising their new ideas was not easy. One participant told me that he had difficulties practising consistent condom use, arguing that if his girlfriend did not protest, then they ended up having unprotected sex. He justified his risky behaviour by saying: "It would not be the first time for me not to use a condom." Another participant reported that reducing his number of sexual partners was a challenge. Although it is difficult to ascertain if the changes registered by the respondents are real and will be sustained, I would like to believe that if they are genuine then this work is a step forward. While my work was primarily research, it 
shows that this work did impact some participants; though regrettably I cannot know if it had a similar impact on any audience members.

\section{Implications for HIV Prevention}

My work with the young men shows that understanding the association of masculinity with risky sexual practices has important implications for HIV and AIDS in Malawi. I would argue that there is a need to recognise the role that dangerous masculinities play in men's attempt to maintain social positions of power, which inevitably increase their HIV risk and leave women vulnerable. Therefore, campaigns that promote the reduction of sexual partners and condom use are woefully inadequate because they clash with, and fail to acknowledge, dominant ideas about masculinity that encourage risky sexual behaviours. These realities require urgent re-adjustment at policy level in anti-HIV programming for men in Malawi. My findings demonstrate, incontrovertibly, that simple messaging about $\mathrm{ABC}$ cannot enable young men to challenge deeply accepted dangerous narratives about masculinity; hence the need for more in-depth, dialogic, and participatory forms of anti-HIV progamming. The methodology I used with the students at Chancellor shows real promise for how a participatory and dialogic, arts-based HIV approach can be useful in engaging young men on issues concerning sexuality and HIV. In order for real change to happen, however, this work needs to more widely practiced, and both young men and women have to be empowered to openly talk about sexuality, gender, and HIV.

${ }^{1}$ John Lwanda, "Tikutha: The Political Culture of the HIV/AIDS Epidemic in Malawi." A Democracy of Chameleons: Politics and Culture in the New Malawi, Ed. Englund, Harri. (Blantyre: Christian Literature Association in Malawi, 2001), 151-165.

${ }^{2}$ Zindaba Chisiza and Amy Bonsall, "The Donor Dependency Syndrome: The Politics of Theatre Funding Structures in Malawi." Platform: Journal of Theatre and Performance Studies, no. 10.2 (2017): 74-89.

${ }^{3}$ Zindaba Chisiza, "Deadly Masculinities: Towards a Theatrical Toolbox for Exploring Identity and HIV with Young Malawian Men." Unpublished PhD thesis (University of Leeds, 2017).

${ }^{4}$ National Statistical Office (NSO) [Malawi] and ICF, Malawi Demographic and Health Survey 2015-16 (NSO and ICF, 2017).

${ }^{5}$ National AIDS Commission National Strategic Plan for HIV and AIDS (Government of Malawi, 2014). 
${ }^{6}$ National Statistical Office (NSO) [Malawi] and ICF, 209.

${ }^{7}$ As above in note 5 .

${ }^{8}$ Chimaraoke Izugbara and Jerry Okal, "Performing Heterosexuality: Male Youth, Vulnerability and HIV in Malawi." in Men and Development: Politicising Masculinities. Ed. Cornwall, Andrea, Edström, Jerker, and Greig, Alain, A (London: Zed Book, 2011): 21-32.

${ }^{9}$ Amy Kaler, “'My Girlfriends Could Fill a Nyanu Nyanu Bus:' Rural Malawian Men's Claims About Their Own Serostatus.” Demographic Research 1, no. 11 (2003): 349-372.

${ }^{10}$ Masculinity refers to socially constructed patterns of behavior performed by most men, patterns which are fluid and changing; they are plural and differ according to social setting.

${ }^{11}$ Izugbara and Okal., 27.

${ }^{12}$ Kennedy Chinyowa, "Theatre Performance as Technology: the Case of Drama in AIDS Education (DramAidE) in Africa." Studies in Theatre and Performance 29, no. 1 (2009): 24.

${ }^{13}$ Lynn Dalrymple, "Has it Made a Difference? Understanding and Measuring the Impact of Applied Theatre with Young People in the South African Context." Research in Drama Education: The Journal of Applied Theatre and Performance 11, no. 2 (2006): 201-218.

${ }^{14}$ Ibid., 210.

15 Ibid., 209.

${ }^{16}$ Federation of African Women Educationists (FAWE) "Empowering Girls through the TUSEME “Speak out" Girls' Empowerment Programme." FAWE News, 13,4 (Nairobi: FAWE, 2005).

${ }^{17}$ Ibid., 7.

${ }^{18}$ As above in note 12 .

${ }^{19}$ In Malawi the model has been implemented in two districts; Mzimba (48 schools) and Kasungu (60 schools).

${ }^{20}$ Dennis Francis, Ed. Acting on HIV: Using Drama to Create Possibilities for Change (Rotterdam: Sense Publishers, 2011), vii.

${ }^{21}$ Liz Walker., Graeme Reid., and Moran Cornell, Waiting to Happen: HIV/AIDS in South Africa: the Bigger Picture (London: Lynne Rienner, 2004), 27.

${ }^{22}$ Gary Baker and Christine Ricardo, "Young Men and the Construction of Masculinity in Sub-Saharan Africa: Implications for HIV/AIDS, Conflict, and Violence." Social Development Paper: Conflict Prevention \& Reconstruction. Paper No. 26 (2005).

${ }^{23}$ Ibid., 16-17.

${ }^{24}$ Jo Salas, Improvising Real Life: Personal Story in Playback Theatre. (New York: Tusitala Publishing, 1996). 
${ }^{25}$ Catherine MacPhail and Catherine Campbell, "'I Think Condoms are Good but, Tai, I Hate Those Things': Condom Use Among Adolescents and Young People in a Southern African Township." Social Science and Medicine 52, no. 11 (2001): 1621.

${ }^{26}$ Augusto Boal, Theatre of the Oppressed. (London: Pluto Press, 1979).

${ }^{27}$ Cohen Cruz, Jan, Ed. A Boal Companion: Dialogues on Theatre Cultural Politics. (London: Routledge, 2006).

${ }^{28}$ MacPhail and Campbell, 1615.

${ }^{29}$ Boal, 122.

${ }^{30}$ In Forum theatre, actors create a short sketch about a political or social problem which is presented to an audience. The audience is then asked to intervene directly, as spect-actors, in the action in order to change it. 